İktisat Politikası Araştırmaları Dergisi -

\title{
Regional Analysis of Skills-Mismatch in Turkish Labor Markets
}

\author{
Türkiye İşgücü Piyasaları'nda Beceri Uyuşmazlığının Bölgesel \\ Ayrımda İncelenmesi
}

\section{Ömer ŞAHIN' ${ }^{1}$}

\begin{abstract}
The difference between the skills and the skills needed in the labor market is called skill mismatch. The literature reveals this skills mismatch problem as an over-education and over-qualification problem in Turkish labor markets. For enterprises, the two hardest employees to find are unqualified workers and workers with vocational training, both bluecollar (VGM,2018). This finding also is supported by high higher-education unemployment (TURKSTAT, 2020). However, earlier studies do not make clear if different regions suffer from these problems uniformly. This study aims to reveal the differences between NUTS-2 regions in suffering from the over-education and over-qualification problem. It extensively uses the Sectoral and Regional Mapping of Productivity and Development in Turkey project, SEGE 2017 report to acquire the development levels of NUTS- 2 regions and TURKSTAT's employment statistics by education and NUTS-2 region. Two crucial findings of this paper are that only the illiterate labor force satisfies enterprises' unqualified labor need and that while less developed regions suffer severely from the over-education and over-qualification problem, more developed regions only suffer from lack of workers with vocational training. This paper will first analyze the current situation in Turkish Labor Markets, followed by the presentation and analysis of data it uses. In the end, these results will be discussed, and policies to improve the situation will be suggested.
\end{abstract}

Keywords: Skills mismatch, Turkish labor markets, Regional labor markets, Labor economics

Jel Code: J08, J21, J24

\begin{abstract}
'Universitat Pompeu Fabra, Department of Political and Social Sciences, Barcelona, Spain
\end{abstract}

ORCID: Ö.Ş. 0000-0002-5176-5383

\section{Corresponding author/Sorumlu yazar: Ömer ŞAHIN, \\ Universitat Pompeu Fabra, Department of Political and Social Sciences, Barcelona, Spain E-mail/E-posta: omer.sahin01@estudiant.upf. edu; omersahin4457@gmail.com}

Submitted/Başvuru: 20.10.2020 Revision Requested/Revizyon Talebi: 14.12.2020

Last Revision Received/Son Revizyon: 14.12.2020

Accepted/Kabul: 14.12.2020

Citation/Atıf: Sahin, O. (2021). Regional analysis of skills-mismatch in Turkish labor markets. Iktisat Politikası Araştırmaları Dergisi - Journal of Economic Policy Researches, 8(1), 1-27. https://doi.org/10.26650/JEPR813711 


\section{Introduction}

According to Turkey's Productivity Development Map Project (Türkiye Verimlilik Gelişim Haritası Projesi), when enterprises are asked which type of employees that they think is hardest to find, the two most common answers are unqualified workers and workers with vocational training (VET workers from this point onwards), both blue-collar positions. What makes this finding even more striking is that the size, location, or sector of the enterprise does not make any difference. With only a single exception, VET workers and unqualified workers are the first two types of workers that enterprises report difficulty finding, regardless of size, sector, and location (VGM, 2018). Considering these answers from enterprises, we should not be surprised by high unemployment rates among university graduates in Turkey. According to TURKSTAT's numbers, higher education graduates constitute the second largest unemployed group, second only to the illiterate labor force (TURKSTAT, 2020).

Manpower Group offers a more comprehensive perspective. According to Talent Shortage Survey (Manpower, 2018), in 2019, 54\% of employers in Turkey could not find the qualified labor force they were looking for. In other words, $54 \%$ of positions in Turkey are either occupied with workers who are not qualified for the job or not occupied at all. These numbers point to an important skills mismatch problem in Turkey.

When we take a look at past studies in this area, we see that Turkey's skills mismatch problem is not about under-education or under-qualification but rather an over-education problem that has been on the rise for a while now. While the percentage of higher education graduates who are under-employed was around 30\% in 2009 (Allen \& Van der Velden, 2009), it was as high as 54\% in 2014 (Kurnaz, 2014). These findings imply that an increasing number of higher education graduates are hired in jobs that do not require a higher education diploma.

The skills mismatch problem affects the economy in many negative aspects. In a labor market that suffers from over or under-qualification, enterprises cannot find workers they need. As a result, enterprises' production efficiency and capacity suffer, and profit margins shrink (Miner, 2014; Zira, 2016). Employees on the other hand, cannot put the skills they acquired as part of their formal education into good use. Jobs they can find might be irrelevant to their field of expertise or do not require their level of education. They will have to settle for a lower wage. If they cannot find jobs, they join the army of unemployed. On the macro level, the economy suffers countrywide. Because less people can participate in the production due to unemployment and enterprises cannot find the employees with the right skills, the overall size of the economy shrinks. Everybody in the economy settles for less: less pay, less employment, less efficiency, and less production. 
There are several studies that focus on the skills mismatch problem in Turkey as a whole. We will mention these studies in the literature review part. Although these earlier works provide an overall picture of the problem, they remain silent on the regional differences. However, the important differences in regional unemployment is a general characteristic of the Turkish labor market, and the skills mismatch problem can intensify this issue. For regions with different development levels, labor force composition by years in education, tech intensity, and added value of production change. Even if they all suffer from the same problem, there is no one-size-fits-all solution. On top of that, these regions interact with each other. Just like products and investments, labor is mobile to a degree as long as it stays within borders of Turkey, and some regions do a better job at attracting the blue-collar workers they need than other regions. This benefits labor markets of some regions while hurting the others.

This study aims to fulfill this gap in the literature in the above-mentioned direction by analyzing the cause, type, and severity of the skills mismatch problem in regions by their development level. In doing so, we will analyze the composition of regional labor forces by education. Our purpose is to determine the groups by education level that suffer from the skills mismatch problem and groups that can fill the positions enterprises need after a fitting training. In addition to these, we will try to understand the migration flows between regions and try to determine the factors that make a region more advantageous in finding the labor force they need. In the end, we will offer our solutions.

In the next part, we will offer the literature review to lay the context of this research. In the second section, we will explain the data sets and methodology we used. In section three, we will present our findings, and finally in last section, we will offer our discussion and limitations.

\subsection{Literature Review}

Although some findings of the literature were already presented in the introduction part, we think that presenting the related studies in one table will be more comprehensive. 
Table 1: Related Literature Review

\begin{tabular}{|c|c|c|c|}
\hline Author(s) & Scope/Data & Topic & Findings for Turkey \\
\hline Galasi, 2008 & $\begin{array}{c}\text { Data on } 25 \\
\text { countries, collected } \\
\text { between } 2004 \text { and } \\
2006\end{array}$ & $\begin{array}{l}\text { Estimation to } \\
\text { educational } \\
\text { mismatches across } \\
\text { countries }\end{array}$ & $\begin{array}{l}-1.4 \% \text { of workers are properly educated for their } \\
\text { positions } \\
-27.9 \% \text { of workers are under-educated for their } \\
\text { positions } \\
-70.8 \% \text { of workers are under-educated }\end{array}$ \\
\hline $\begin{array}{l}\text { Allen and } \\
\text { Van der }\end{array}$ & $\begin{array}{l}16 \text { REFLEX } \\
\text { countries between }\end{array}$ & $\begin{array}{l}\text { Experiences of } \\
\text { higher education }\end{array}$ & $\begin{array}{l}\text { - Higher education graduates search jobs for more } \\
\text { than } 6 \text { months on average. }\end{array}$ \\
\hline Velden, 2009 & $\begin{array}{l}1999 \text { - } 2005 \text { and } \\
5 \text { HEGESCO } \\
\text { countries between } \\
20002 \text { - } 2008\end{array}$ & $\begin{array}{l}\text { graduates in } \\
\text { labor market five } \\
\text { years following } \\
\text { graduation }\end{array}$ & $\begin{array}{l}\text { - } 10.8 \% \text { of graduates are unemployed } 5 \text { years after } \\
\text { graduation. } \\
\text { - } 30 \% \text { of graduates are hired below their skill level. }\end{array}$ \\
\hline $\begin{array}{l}\text { OECD } \\
\text { Employment } \\
\text { Outlook, } \\
2011\end{array}$ & $\begin{array}{l}\text { OECD countries, } \\
\text { South Africa and } \\
\text { Switzerland }\end{array}$ & $\begin{array}{l}\text { Employment } \\
\text { dynamics across } \\
\text { OECD countries for } \\
2011 \text { calendar year }\end{array}$ & $\begin{array}{l}\text { - Over-qualification is } 25.2 \% \text { on average. } 40 \% \text { in } \\
\text { Turkey (third highest across all countries). } \\
\text { - Under-qualification is } 22.2 \% \text { on average. } 2.8 \% \text { in } \\
\text { Turkey (lowest across all countries). }\end{array}$ \\
\hline SETA, 2012 & $\begin{array}{l}\text { Interviews with } \\
107 \text { companies and } \\
\text { surveys with } 2018 \\
\text { companies in } 2012\end{array}$ & $\begin{array}{l}\text { Analyzing needs, } \\
\text { problems and } \\
\text { current dynamics } \\
\text { of Turkish labor } \\
\text { market }\end{array}$ & $\begin{array}{c}-37.1 \% \text { of employees cannot find workers with } \\
\text { vocational skills. } \\
-23.6 \% \text { of employers cannot find workers with } \\
\text { vocational experience } \\
-57.4 \% \text { of employers think they will need } \\
\text { professional and technical skills more in the following } \\
\text { year } \\
-76.7 \% \text { of employers say finding right worker is } \\
\text { getting harder every year }\end{array}$ \\
\hline $\begin{array}{l}\text { Aşık, } 2013 \\
\text { (TEPAV) }\end{array}$ & $\begin{array}{l}\text { TURKSTAT } 2011 \\
\text { Household Labor } \\
\text { Force Survey }\end{array}$ & $\begin{array}{l}\text { Estimation of } \\
\text { under-employment } \\
\text { in Turkish labor } \\
\text { markets }\end{array}$ & $\begin{array}{c}-29.9 \% \text { of higher education graduates do not need } \\
\text { higher education diploma for their job. } \\
-8.8 \% \text { of higher education graduates work as } \\
\text { unqualified workforce. } \\
\text { - } 47 \% \text { increase in under-employment between } 2004 \\
\text { and } 2011\end{array}$ \\
\hline Kurnaz, 2014 & $\begin{array}{l}\text { Data from URKSTAT } \\
\text { Household Labor } \\
\text { Force Surveys } \\
\text { between } 1988 \text { and } \\
2014\end{array}$ & $\begin{array}{l}\text { Effect of higher } \\
\text { education on } \\
\text { employability }\end{array}$ & $\begin{array}{l}\text { - Over-education rate among young higher education } \\
\text { graduates rose from } 38.3 \% \text { to } 54.0 \% \text { from } 2004 \text { to } \\
\qquad 2014 \\
\text { - Graduates who suffer the most from over-education } \\
\text { work in customer services and other service sectors. }\end{array}$ \\
\hline
\end{tabular}

In Table 1, the first thing to note is that the only research stating an under-education problem in the Turkish labor markets is Galasi (2008), who found that $71 \%$ of the employees in Turkey were under-educated between 2004 and 2006. The following studies consistently find an over-education problem in Turkish labor markets, which seems to intensify through the years. While 30\% of higher education graduates were under-employed in 2009 (Allen and Van der Velden, 2009), the number climbed up to 54\% in 2014 (Kurnaz, 2014). On the other hand, over-qualification rose from 40\% in 2011 (OECD, 2011) to 47\% in 2013 (Aş1k, 2013). Finally, according to SETA (2012), the percentage of enterprises that could not find workers with vocational training increased from $37 \%$ to $77 \%$ over the years. 


\section{Methodology}

We used several data sources. The first data source is the findings of the Turkey Productivity Development Map Project (Türkiye Verimlilik Gelişim Haritası Projesi), which was undertaken by the Directorate of Productivity in The Ministry of Industry and Technology of Turkey in 2016. The project conducted a detailed 109 question survey for its data collection, covering broad areas from employee profile, capital structure, resource efficiency, technology and innovation, production network, and executive and organizational structure. The sample of 10,063 enterprises was adjusted to represent 218,193 enterprises registered in the Enterprise Information System of the Ministry of Science and Technology (Girişimci Bilgi Sistemi). The project represents small-scale (1 - 19 employee) enterprises registered in the Enterprise Information System at 95\% significance level with a $\pm 7.5 \%$ confidence interval and all large scale (20+ employees) enterprises at $80 \%$ significance level with a $\pm 7.5 \%$ confidence interval (VGM, 2018). For this paper, we will use a single question which asks enterprises to specify the employees they struggle to find across all skill levels.

The second group of data used for this study is from TURKSTAT's Labor Force Indicators for the fiscal year of 2018. We used data retrieved from TURKSTAT in order to understand whether there are regional differences regarding the percentage of enterprises that express difficulties in finding unqualified and VET workers. For this purpose, we will use the statistics concerning the composition of the labor force by education level, local labor force participation rates, and unemployment rates of different education levels.

Finally, we utilized the Socioeconomic Development Ranking (Sosyo-Ekonomik Gelişmişlik Sıralaması Araştırması), or the SEGE 2017 report, of the Directorate of Development in the Ministry of Industry and Technology to categorize regions by their development levels in NUTS-2 level (KAGM, 2017). Throughout the paper in all graphs, we color-coded regions according to their development levels retrieved from the SEGE 2017 report. Readers should note that, unlike the first two data which are for the 2018 fiscal year, the SEGE is for 2017. We do not believe this is a problem since we do not expect any major changes in regional development levels on a year to year basis.

Table 2 presents some of the descriptive statistics about the regions and their respective sample sizes together. In the first two columns, we present NUTS-1 and NUTS-2 keys for different regions of Turkey. The third column shows the development levels of regions according to the SEGE 2017 report. In the fourth and last column, we presented the sample size for each region of Turkey's Productivity Development Map Project. We will analyze the relationship between regional dynamics and the difficulty of finding unqualified or VET workers on NUTS-2 level. 
Table 2: NUTS Region Key and Sample Size by Region

\begin{tabular}{|c|c|c|c|}
\hline NUTS-1 & NUTS-2 & Development Level & Sample Size \\
\hline Istanbul Region (TR1) & Istanbul Subregion (TR10) & 1 & 1519 \\
\hline \multirow{2}{*}{ West Marmara Region (TR2) } & Tekirdağ Subregion (TR21) & 2 & 357 \\
\hline & Balıkesir Subregion (TR22) & 2 & 304 \\
\hline \multirow[t]{3}{*}{ Aegean Region (TR3) } & Izmir Subregion (TR31) & 1 & 640 \\
\hline & Aydın Subregion (TR32) & 2 & 362 \\
\hline & Manisa Subregion (TR33) & 2 & 368 \\
\hline \multirow[t]{2}{*}{ East Marmara Region (TR4) } & Bursa Subregion (TR41) & 1 & 613 \\
\hline & Kocaeli Subregion (TR42) & 1 & 524 \\
\hline \multirow[t]{2}{*}{ West Anatolia Region (TR5) } & Ankara Subregion (TR51) & 1 & 539 \\
\hline & Konya Subregion (TR52) & 2 & 359 \\
\hline \multirow[t]{3}{*}{ Mediterranean Region (TR6) } & Antalya Subregion (TR61) & 1 & 326 \\
\hline & Adana Subregion (TR62) & 2 & 412 \\
\hline & Hatay Subregion (TR63) & 3 & 326 \\
\hline \multirow[t]{2}{*}{ Central Anatolia Region (TR7) } & Kırıkkale Subregion (TR71) & 3 & 280 \\
\hline & Kayseri Subregion (TR72) & 2 & 354 \\
\hline \multirow[t]{3}{*}{ West Black Sea Region (TR8) } & Zonguldak Subregion (TR81) & 2 & 253 \\
\hline & Kastamonu Subregion (TR82) & 3 & 236 \\
\hline & Samsun Subregion (TR83) & 3 & 327 \\
\hline East Black Sea Region (TR9) & Trabzon Subregion (TR90) & 3 & 329 \\
\hline \multirow[t]{2}{*}{ Northeast Anatolia Region (TRA) } & Erzurum Subregion (TRA1) & 3 & 232 \\
\hline & Ağr1 Subregion (TRA2) & 4 & 151 \\
\hline Central East Anatolia & Malatya Subregion (TRB1) & 3 & 261 \\
\hline Region (TRB) & Van Subregion (TRB2) & 4 & 198 \\
\hline \multirow[t]{3}{*}{ Southeast Anatolia Region (TRC) } & Gaziantep Subregion (TRC1) & 3 & 387 \\
\hline & Şanlıurfa Subregion (TRC2) & 4 & 239 \\
\hline & Mardin Subregion (TRC3) & 4 & 204 \\
\hline Total & & & 10100 \\
\hline
\end{tabular}

Source: VGM, KAGM, created by Author

For this paper, we set our confidence level at $95 \%$ for the regressions we ran between regional variables and enterprises that expressed difficulty in finding unqualified VET workers. Although we presented a couple of graphs with confidence levels lower than $95 \%$ (but higher than 90\%) to give an indication of the relationship between respective variables, we refrained ourselves from putting too much weight into data with smaller confidence intervals than $95 \%$ during our interpretations.

Throughout the paper, we have presented several tables and charts to illustrate the relationship between the regional characteristics and difficulty of finding unqualified or VET workers. We also present the respective correlation coefficients and p-values for the regressions we ran for the variables presented on the $\mathrm{x}$ and y-axes. In addition to these statistical values, we have also presented trend lines with a shade indicating the $95 \%$ confidence interval. As stated above, in all tables, regions are color-coded 
according to their development levels. A legend for color-codes is presented on the right side of each table.

\section{Findings}

In this part, we have presented our data and findings in three parts. In 3.1, we analyze the relationship between difficulties in finding workers with vocational training (VET workers) and unqualified workers by regions and development level. In 3.2 and 3.3, we analyze the relation between populations' education levels in regions and the difficulties in finding an unqualified labor force (3.2) and VET workers (3.3).

\subsection{Positions Enterprises Find Most Difficult to Fill}

According to the Turkey Productivity Development Map Project, in all the NUTS-2 regions, enterprises have the most trouble in finding VET workers and unqualified workers. Table 3 below shows the percentage of enterprises that expressed difficulties in finding VET workers on the x-axis, and percentage of enterprises which expressed difficulties in unqualified workers on the $y$-axis. The p-value we got for the regression is 0.00097 . The shade of the trend line marks the $95 \%$ confidence interval.

It is important to note that the trend line on Table 3 below omits TR10(Istanbul), the outlier region where enterprises can find both unqualified workers and VET workers relatively easier. Istanbul has a population of 15 million, three times of Ankara, which is the second biggest province and capital of Turkey. We know that in larger labor markets, employees can find jobs fitting to their field and skill level while enterprises can find employees they need easier (Berlingieri, 2019). Since this condition only applies to TR10, we omitted TR10 for the trend line.

The first thing to note on Table $\mathbf{3}$ is that there is considerable regional variation. In addition, there is a negative correlation between the difficulty to find unqualified workers and the difficulty to find VET workers. In regions where it is relatively easier for enterprises to find VET workers, it is relatively harder to find unqualified workers and vice versa. What's more, the regions form clusters according to their development levels. We will see these clusters throughout the paper. We believe these clusters are due to the similarities of economic complexity and technology intensity and value-added in regions with the same development levels. Regions with development level 4 sit at the bottom-right corner of Table 3. This means about 85 to $90 \%$ of the enterprises in these least developed regions expressed difficulty in finding VET workers. Enterprises suffer the most from difficulties in finding VET workers in development level 4 regions. Unlike the difficulties they suffer in finding VET workers, enterprises in the least developed regions of Turkey express relatively 
less difficulty in finding unqualified workers. Therefore, we may claim that there is a division between the regions with respect to the labor qualifications they face difficulty to fill in.

Table 3: Percentage of Enterprises with Difficulties in Finding Unqualified Worker and VET Worker in Each NUTS-2 Region

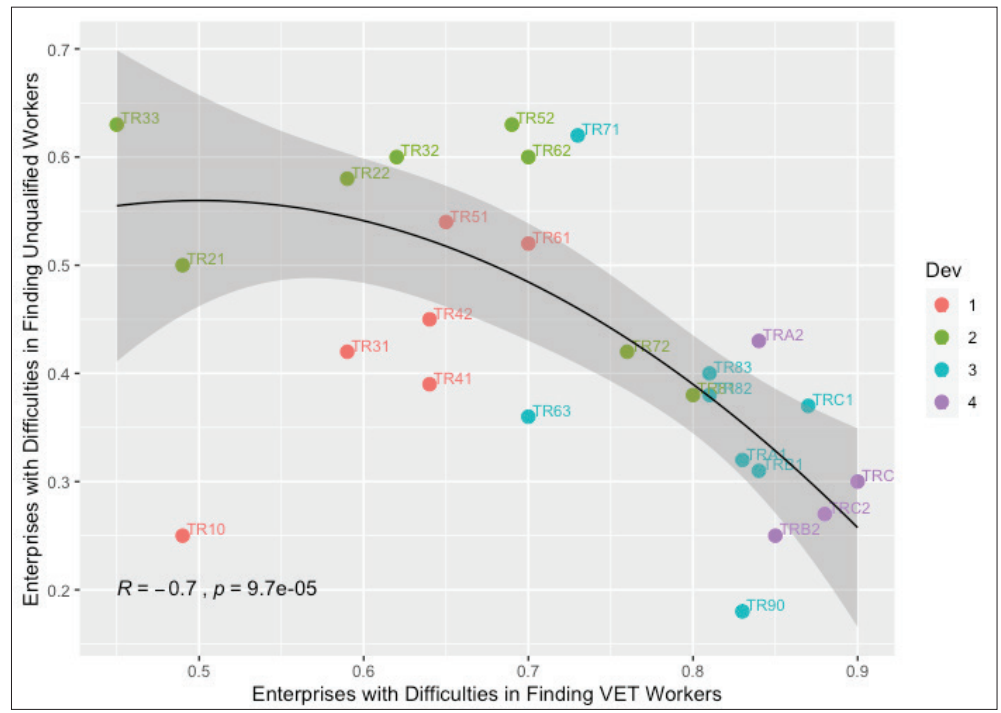

Source: VGM and TURKSTAT, Created by Author

Development level 3 regions show similar results to level 4 regions. Around $70 \%$ of enterprises located in the TR63 and TR71 regions cannot find VET workers. In the remaining six regions, this number is between 80 to $85 \%$. In development level 3 regions, finding unqualified workers is harder compared to level 4 regions but easier compared to level 1 and 2 regions. Except TR71, less than $40 \%$ of enterprises express difficulties in finding unqualified workers. This number is slightly higher than $60 \%$ in TR71, which is an exceptionally higher percentage compared to the rest of the level 3 regions.

The regions that suffers the most from the unavailability of unqualified workers are level 2 regions. About 50 to $65 \%$ of the enterprises cannot find unqualified labor. Two exceptions that sit far away from their level 2 counterparts are TR72 and TR81, where only about 40\% of enterprises express difficulties in finding the unqualified workforce they need. In finding unqualified labor, level 1 regions are in a more advantageous position with only 40 to 55\% of enterprises not being able to find unqualified labor. 
When we check the percentage of enterprises that cannot find VET workers in level 1 and 2 regions, we obtain interesting results. Level 1 and 2 regions spread across the spectrum from $45 \%$ at the lowest to $80 \%$ at the highest. The regions where less than $65 \%$ of enterprises cannot find VET workers are all located in the west of Turkey while regions that score higher than $70 \%$ are all located in the east. The only exception here is TR51, which is Ankara. Enterprises in Ankara can find VET workers as easy as their western-located counterparts although Ankara is located relatively in the east, but this is not surprising since Ankara is ranked first in terms of development indicators, is the capital of Turkey, and has the second largest population, after Istanbul (TR10). Between level 1 and 2, geographical location plays a decisive role in finding VET workers, and the $65 \%$ mark separates advantaged and disadvantaged regions.

\subsection{Characteristics of Regions Where Enterprises Cannot Find Unqualified Labor}

In this part, we analyze the relationship between the percentage of enterprises that express difficulty in finding unqualified labor and the composition of labor force by education level in the NUTS-2 regions.

After we ran our regressions between each education level and the percentage of enterprises that expressed difficulties in finding unqualified workers, we found that illiterates are the only education level that has a statistically significant effect on difficulty in finding unqualified workers. For all other regressions, we got very high p-values to offer a meaningful information. This means the difficulty of finding unqualified labor is only affected by the percentage of illiterates in labor force. Thus, we only brought over the graph with the percentage of illiterates. We will discuss the implications of the low p-values for all education levels except illiterates and parallels with other countries in the discussion section. We also added Table 4 below to show p-values of regressions we ran for each education level. We will explain why we believe this is the case in the discussion section.

Table 4: $R$ and p-values for Regressions between percentage of Enterprises That Find Unqualified Workers Hard and Different Education Levels

\begin{tabular}{lcc}
\hline & R value & p-value \\
\hline Illiterates in Labor Force & -0.5 & 0.0091 \\
Portion of Labor Force without & 0.014 & 0.94 \\
$\begin{array}{l}\text { High School Diploma } \\
\text { Percentage of High School }\end{array}$ & 0.2 & 0.33 \\
$\begin{array}{l}\text { Graduates } \\
\text { Percentage of Higher Education }\end{array}$ & 0.17 & 0.4 \\
Graduates & & \\
\hline
\end{tabular}

Table 5 below shows the percentage of enterprises that express difficulties in finding unqualified workers on the $\mathrm{x}$-axis and the portion of illiterates in the labor force in each respective NUTS-2 region on y-axis. We have a 0.01 significance level for this regression. 
Although less clear, regions at the same development level form clusters again. Level 1 and 2 regions are clustered towards the bottom right of the table while the level 3 and 4 regions are clustered on the top left. As is visible on the trend line, there is a negative correlation between the percentage of illiterates in a region's labor force composition and the percentage of enterprises that struggle to find unqualified labor. In other words, in regions where the portion of illiterates is higher in labor force, enterprises can find unqualified labor they need easier.

As seen in the table, the least developed regions have the most illiterates in their labor force. Around $10 \%$ of the labor force in regions with a development level of 4 are illiterate. In these regions, less than $30 \%$ of enterprises state that they had difficulties in finding unqualified labor force. The region that is away from the trend line here is the TRA2 region, which is Ağr1 Subregion. Although TRA2 has the highest percentage of illiterates in its local labor force, more than $40 \%$ of enterprises expressed difficulties in finding unqualified labor. Despite TRA2, we can say in development level 4 regions, where the percentage of illiterate is highest, enterprises can find unqualified labor the easiest.

Enterprises in development level 3 regions suffer slightly more compared to least developed regions in finding an unqualified labor force. The illiterate labor force constitutes between 4 to $8 \%$ of the labor force in these regions. As a result, 30 to $40 \%$ of the enterprises stated that they could not find unqualified labor in these regions. This percentage interval is lower than the level 1 and 2 regions and higher than the level 4 regions on average. The two exceptions here are TR90, which is the Trabzon Subregion, where enterprises could find unqualified labor relatively easier despite having less illiterates in labor force, and TR71, which is Kırıkkale Subregion which shows similar characteristics to level 2 regions, having a low illiterate percentage and high difficulty in finding unqualified labor. 
Table 5: Percentage of Enterprises That Cannot Find Unqualified Workers and Portion of Illiterate in Labor Force by NUTS-2 Region

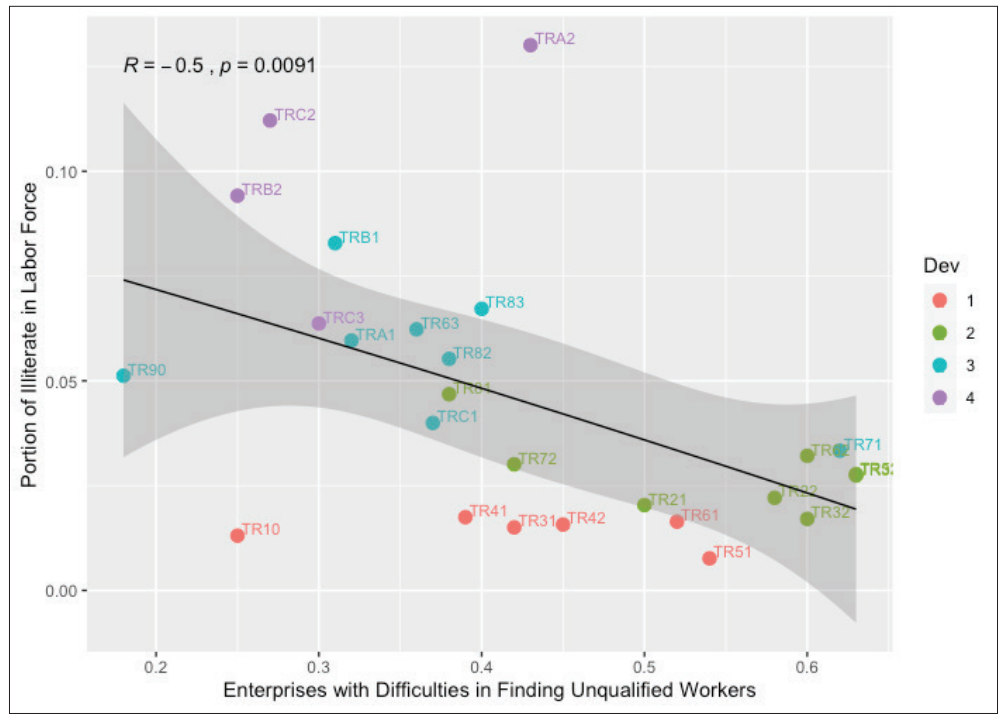

Source: VGM and TURKSTAT, Created by Author

Development level 2 regions suffer the most from the lack of unqualified labor. About $2.5 \%$ of the level 2 regions' labor force is illiterate. While this means level 2 regions have more illiterates than level 1 regions, finding unqualified labor for enterprises in level 2 regions is harder. This is an interesting finding that we will explain in the discussion section.

This does not mean enterprises in level 1 regions can find unqualified labor force as much as they want though. Only around $2 \%$ of the labor force in most developed regions are illiterates. While enterprises in these regions struggle slightly less to find unqualified labor compared to their level 2 counterparts, 40 to $55 \%$ of enterprises expressed that they struggled to fill positions that require no qualifications. Enterprises in level 1 regions suffer from lack of unqualified workers slightly less than level 2 regions and more than level 3 and 4 regions.

\subsection{Characteristics of Regions Where Enterprises Cannot Find VET Workers}

In this part, we will analyze the relationship between the percentage of enterprises that stated they had difficulties in finding VET workers and the educational composition of different regions. We will start with the percentage of illiterates in labor force. 
When we look for the relationship between the percentage of illiterates in the labor force and the percentage of enterprises that expressed difficulties in finding VET workers, there is a big change in trends compared to unqualified labor. As seen in Table 5, a higher illiterate labor force portion helps enterprises find unqualified labor. This is not the case for VET workers. As apparent in Table 6, in regions with the highest percentage of an illiterate population, enterprises struggle the most to find VET workers. There is a positive correlation between the percentage of illiterates in the labor force and the percentage of enterprises who expressed difficulties in finding VET workers. This means that the higher the share of illiterates in the labor force, harder it is to find VET workers. The trend line here has an exponential shape, and this relationship is significant at a 0.00035 level.

In level 4 regions, where the percentage of illiterates in the labor force is the highest, 85 to $90 \%$ of the enterprises expressed difficulties in finding VET workers. As a result, in Table 6 below, the least developed regions are clustered in the top right corner of the graph. For level 3 regions, though the percentage of illiterates in the labor force falls by about $5 \%$ on average, more than $80 \%$ of enterprises still expressed difficulties in finding VET workers. Enterprises in level 3 and 4 regions struggled to find VET workers more when compared to enterprises in level 1 and 2 regions.

Between level 1 and 2 regions, there is a slight difference in the portion that illiterates hold in labor force. The most developed regions of Turkey are in slightly better shape than level 2 regions. While this distinction is slim, it is apparent. The bigger distinction comes from the geographic privilege mentioned in part 3.1. though. Although the eastern level 1 and 2 regions have a similar share of illiterates in their labor forces compared to their western counterparts, enterprises expressed difficulties in finding VET workers at a much higher percentage in the east. The privileged western club displays its advantage the most in this regression compared to rest. 
Table 6: Percentage of Enterprises That Cannot Find VET Workers and Portion of Illiterate in Labor Force by NUTS-2 Region

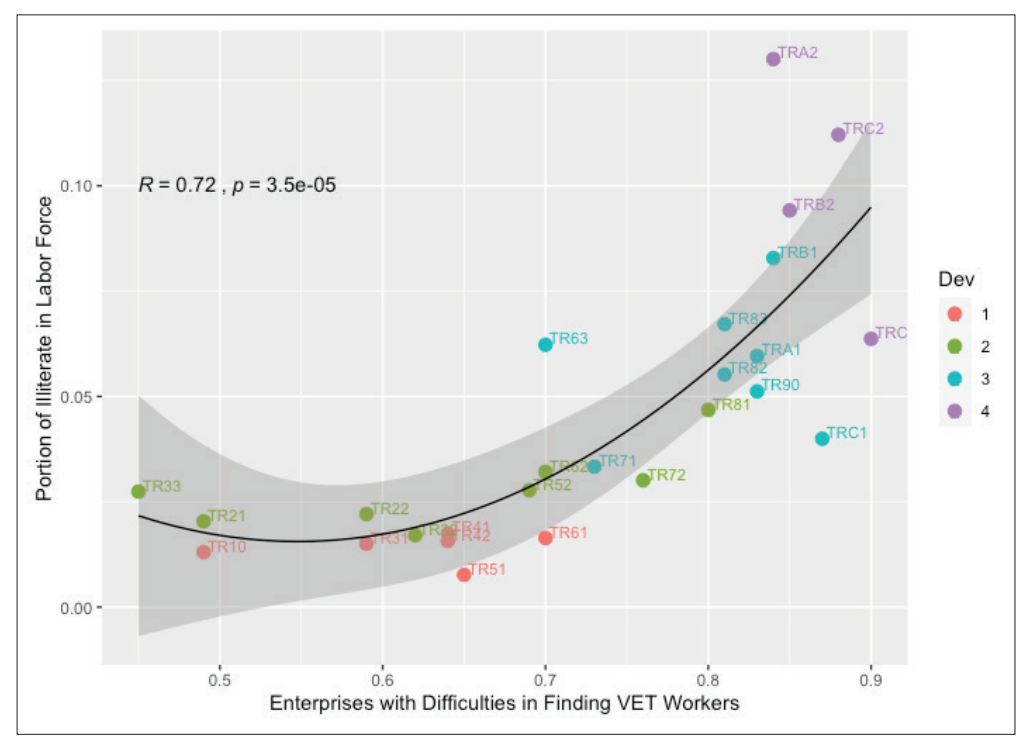

Source: VGM and TURKSTAT, Created by Author

When we run regression between the percentage of the labor force without a high school diploma and the difficulty of finding VET workers, we got a p-value of 0.055 . Although clusters are apparent again according to the development levels of regions, we will refrain ourselves from over-interpreting the data and giving it more weight than it deserves since the relation is not significant at a 95\% confidence level. We will carry over Table 7 below and confine ourselves to saying that if a region is more developed and the share of labor force without a high school diploma is lower, enterprises complain less on not being able to find VET workers. If a region is relatively less developed and the percentage of labor force without a high school diploma is higher, enterprises struggle more to find VET workers. 
Table 7: Percentage of Enterprises That Cannot Find VET Workers and Portion of Labor Force without High School Diploma by NUTS-2 Region

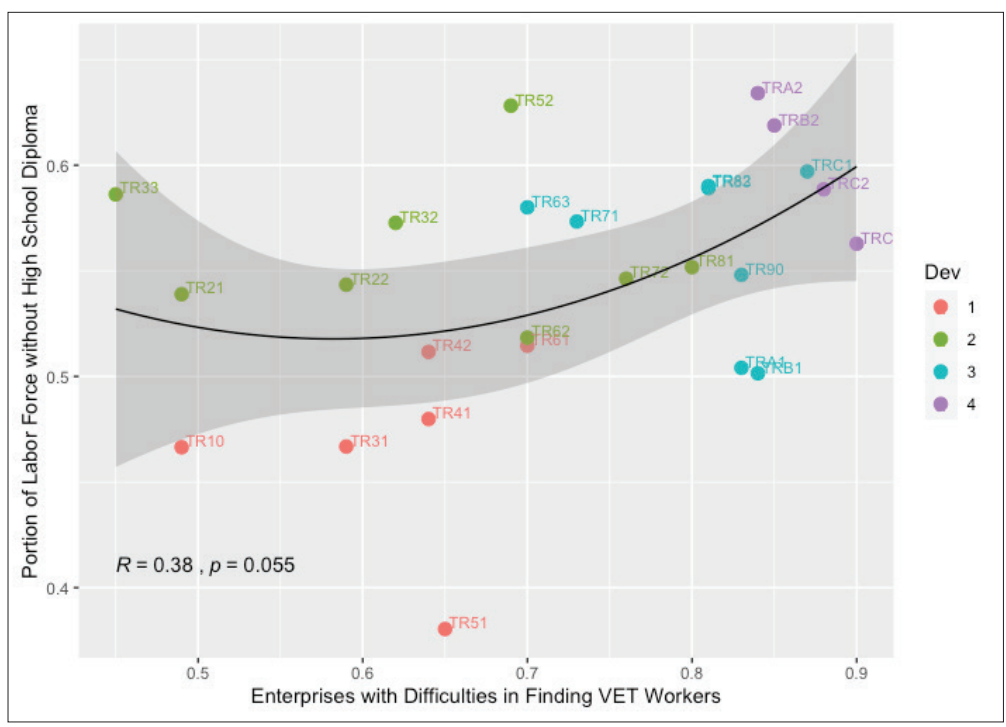

Source: VGM and TURKSTAT, Created by Author

In Table 8, the relationship between the percentage of high school graduates in the local labor force composition and the percentage of enterprises that struggled to find VET workers are presented. There is a negative correlation with a p-value of 0.0031 . This means there is a significant relationship between the percentage of high school graduates in the local labor force composition and the percentage of enterprises which expressed difficulties in finding VET workers. Unlike the percentage of illiterates in the labor force, this correlation is negative. This means, if a region has less high school graduates, enterprises struggle more to fill positions that require VET workers. If a local labor force has more high school graduates, it is easier to find VET workers. Clusters appear in Table 8 as well.

In development level 4 regions, where enterprises struggle the most to find VET workers, the percentage of high school graduates constitute as low as $13 \%$ of the local labor force at the lowest and only $18 \%$ at the highest. The only comparable region to development level 4 regions in high school graduate rate is TR52, which is a level 2 region. However, in TR52, enterprises do not express difficulties in finding VET workers as much as development level 4 regions. In development level 3 regions, 17 to $21 \%$ of the labor force are high school graduates. Level 3 regions have more high school graduates, and in these regions, a smaller percentage of enterprises expressed difficulties in finding VET workers compared to level 4 regions. 
Apart from TR52, high school graduates constitute 20 to $23 \%$ of the local labor force in development level 2 regions. In TR52, 16\% of the labor force are high school graduates, which is an exceptionally low number for a level 2 region. As stated before, level 2 regions are spread across the spectrum in percentage of enterprises that expressed that they could not find VET workers. The distinction here is a geographic one.

Table 8: Percentage of Enterprises That Cannot Find VET Workers and Portion of Labor Force with High School Diploma by NUTS-2 Region

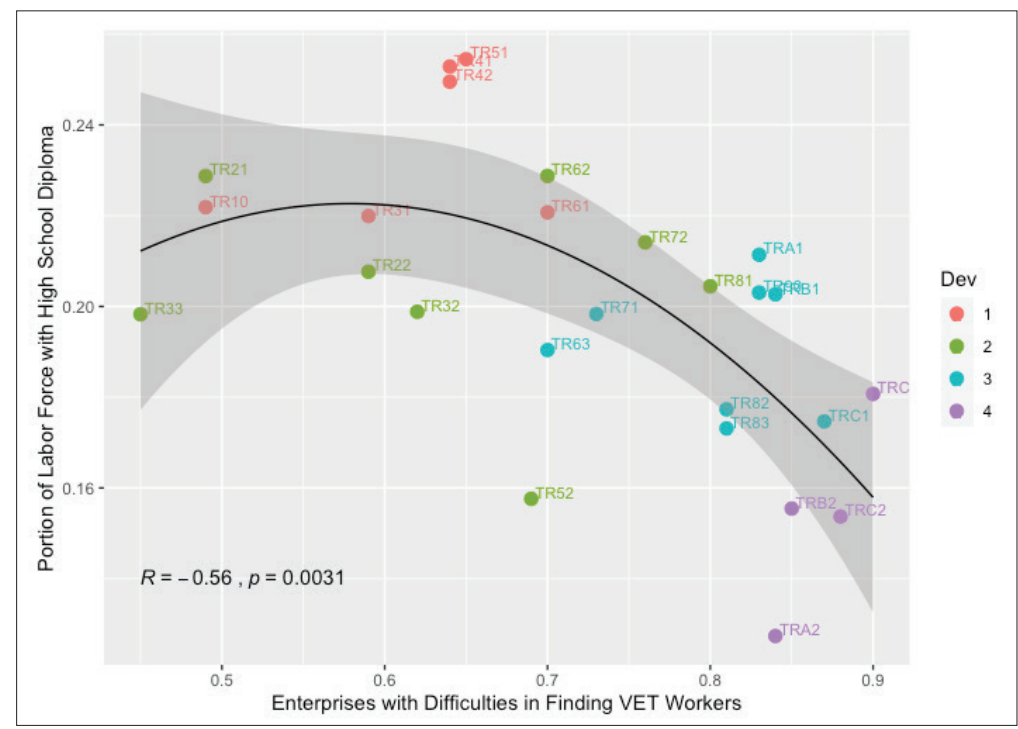

Source: VGM and TURKSTAT, Created by Author

Development level 1 regions are in two groups in terms of percentage of high school graduates in labor force. While in TR10, TR31 and TR61, 22\% of their labor force are high school graduates, TR41, TR42, and TR51 have a rate of about $25 \%$ of their labor force being high school graduates. While these percentages are close, the clusters they form are quite apparent in Table 8. In terms of the percentage of high school graduates in their labor force, level 1 regions are better educated than the rest.

Below is Table 9, which shows the percentage of enterprises that expressed difficulty in finding VET workers on the x-axis and the percentage of higher education graduates in the local labor force on the y-axis. Just like with high school graduates, a negative correlation between variables is apparent here. This means if a region has less higher education graduates in its labor force, more of the enterprises in that region express difficulties in finding VET workers. The graph has a p-value of 0.0059 , which means it is statistically significant at a $99 \%$ level. 
In development level 4 regions, where enterprises struggle the most to find VET workers, less than $15 \%$ of the labor force are higher education graduates. The only exception here is the TRC 3 region. where higher education graduates constitute $20 \%$ of the local labor force. Level 3 regions are in a slightly better shape compared to level 4 regions with 17 to $23 \%$ of their labor force being higher education graduates.

Table 9: Percentage of Enterprises That Cannot Find VET Workers and Portion of Labor Force with Higher Education Diploma by NUTS-2 Region

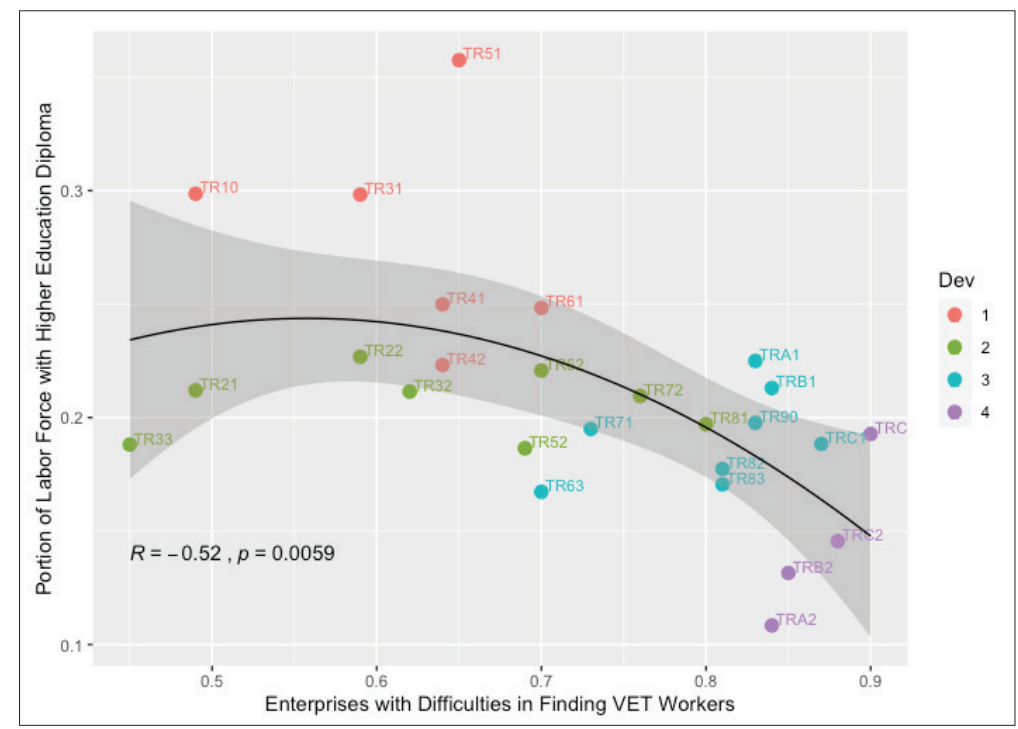

Source: VGM and TURKSTAT, Created by Author

When we look at the two most developed regions, we see how level 1 regions distance themselves from the rest in the percentage of higher education graduates. The five regions with the highest percentage of higher education graduates are all development level 1 regions. The three biggest metropoles of Turkey, which are TR10(Istanbul), TR31(Izmir) and TR51(Ankara), have especially high percentages of higher education graduates.

Again, between level 1 and 2 regions, the percentage of higher education graduates does not make the impact of geographical location obsolete. The westernmost regions hold their advantage in attracting VET workers. We believe this advantage of geographical location between level 1 and 2 regions reflects on the difficulty of finding VET workers in level 3 and 4 regions as well. We will discuss this in the following part. 
In short, we can conclude that the percentage of illiterates in labor force has a negative impact on enterprises' chances to find workers with vocational training while the percentage of high school and higher education graduates improve enterprises' chances.

\section{Discussion, Suggestions and Conclusion}

In Turkey, VET workers and unqualified workers are two hardest employees for enterprises to find at all regions. Our first finding is that considering all regions, 20 to $65 \%$ of enterprises express difficulties in finding unqualified labor in their local labor market while this interval is 45 to $90 \%$ for VET workers. In this aspect, between these two hardest employees to find in Turkey, it is harder to find VET workers. In every region except TR21 and TR33, percentage of enterprises that express difficulties in finding VET workers is higher than percentage of enterprises that express difficulties in finding unqualified labor. The outlier is the TR10 region (Istanbul) where remarkably low percentages of enterprises express difficulties in finding both unqualified labor and VET workers. We believe that this finding is due to the big labor pool enterprises in Istanbul, thanks to its huge population of the city. In Istanbul, 25\% of enterprises express difficulties in finding unqualified labor and 49\% in VET workers. Although these percentages are lower than the rest, they are not low by any means and high enough to cause problems in production efficiency and unemployment.

\subsection{Discussion, Suggestions and Conclusion for Unqualified Workers}

When we analyze the relationship between education levels and the difficulty of finding unqualified workers, we see that the only education level that has a statistically significant effect on the difficulty of finding unqualified workers is the percentage of illiterates in the labor force. Although future studies should examine this relationship further, we believe a labor market that consists of a demand for unqualified labor and a supply of an illiterate labor force might be relatively isolated from the rest of the skill levels. Either other education groups might not be interested in doing unqualified work, or enterprises might not be able to offer sufficient wages to attract other education groups to unqualified work. In this aspect, we believe unqualified and unskilled labor is relatively more difficult to substitute with skilled and qualified labor. This finding and interpretation is parallel with Steiner and Mohr. The pair state the inelasticity of substitution for unskilled by skilled labor in most sectors of the German economy (1998).

Table 10 shows the percentage of enterprises which expressed difficulties in finding unqualified workers on the $\mathrm{x}$-axis and the unemployment of higher education graduates on the $y$-axis. This is the only unemployment rate by education level that has a statistically significant relationship and the only one we brought over. The p-value of this regression is 0.021. Table $\mathbf{1 0}$ indicates that in regions where enterprises struggle more to find unqualified 
labor, unemployment of higher education graduates is lower. Wherever enterprises are able to find unqualified labor easier, the unemployment of higher education graduates is higher.

We believe this is a reflection of the development levels of regions. In more developed regions, the population is also better educated. Fewer illiterates in the local labor force also means it is more difficult for enterprises to find unqualified labor. For level 3 and 4 regions, less than $40 \%$ of enterprises express difficulties in finding unqualified labor. Level 1 and 2 regions are located at more than $40 \%$. The exception here is that development level 1 regions can find unqualified labor easier compared to level 2 regions, but again, this is not surprising. Development level 1 regions are also the most populous regions of Turkey, and in larger labor force pools, it is easier for enterprises to find the labor force they need (Berlingieri, 2019). This also explains the outlier TR10, a level 1 region with a population of 16 million where enterprises can find unqualified labor a lot easier compared to other level 1 regions.

Table 10: Relationship Between Difficulty of Finding Unqualified Workers and Unemployment of Higher Education Graduates by NUTS-2 Region

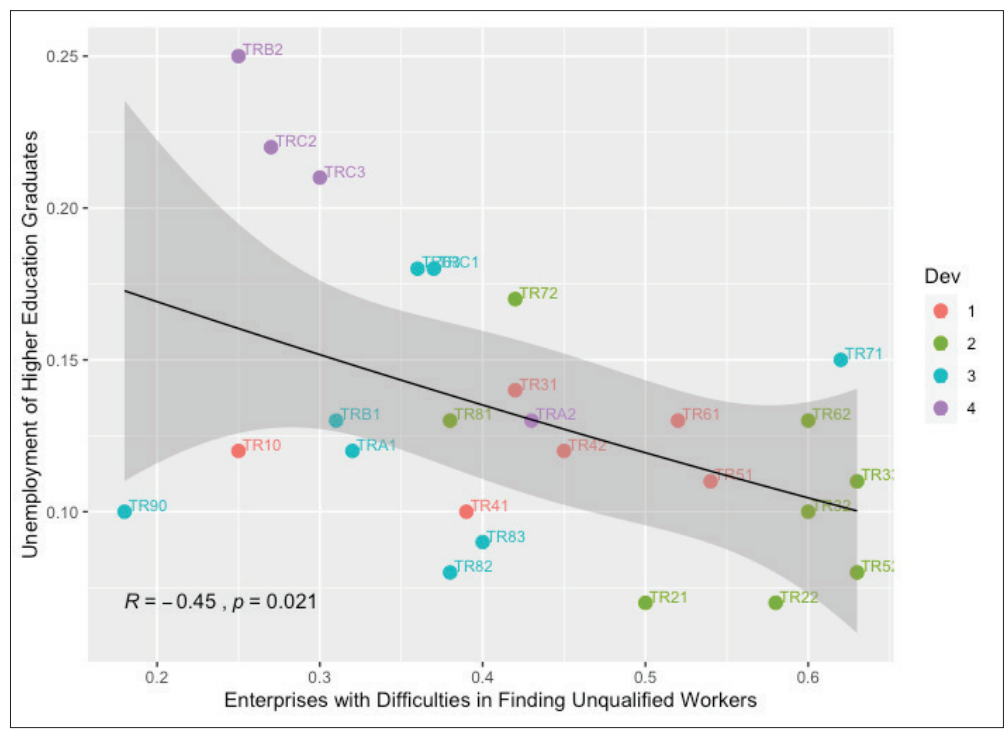

Source: VGM and TURKSTAT, Created by Author

The population could help regions even further though. In Table 11 below, the percentage of enterprises that expressed difficulties in finding unqualified labor is presented on the $\mathrm{x}$-axis and labor participation rates of the illiterate population are presented on the $\mathrm{y}$-axis. The problem in level 1 and 2 regions is not that these regions lack an illiterate population but that they lack an illiterate labor force. This is even true for level 3 and 4 regions. Although 
labor force participation rates of illiterates are remarkably higher in less developed regions, there is still an untapped potential and unsatisfied need of enterprises. By encouraging the illiterate population to participate in the labor force, we might help enterprises find the unqualified labor force they need.

However, if there are jobs for the illiterates out there, why do they not participate in the labor force? While we do not know exactly, we have a couple of potential answers. First, it might be the case that, even though enterprises actually need unqualified labor, they cannot afford to pay them the minimum wage. The added value an unqualified worker creates might not be enough to cover his or her minimum wage for these enterprises. Thus, even though enterprises need workers and workers need jobs, they might not be able to match.

Second, the unqualified labor force might be unaware of the open positions for whatever reason. İŞKUR, the government institution to help people find jobs, might be the answer here. Increasing the communication between the untapped labor force and enterprises in need might improve the labor force fluidity and bring these two sides, enterprises and illiterates, together.

Table 11: Relationship Between Difficulty of Finding Unqualified Workers and Labor Force Participation of Illiterates by NUTS-2 Region

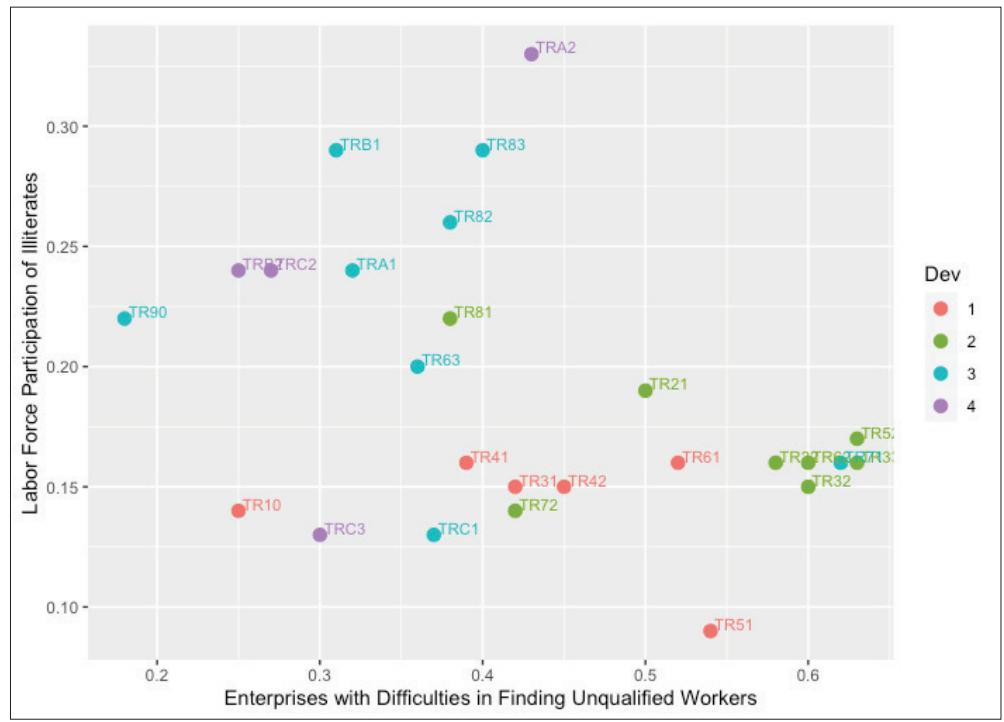

Source: VGM and TURKSTAT, Created by Author

Another problem might be the lack of soft skills. Unlike hard skills that are vocational and technical, soft skills are human skills such as effective communication, language 
knowledge, punctuality, responsibility, or basic math. It is true that these enterprises are looking for unqualified labor, but even in this case, illiterates might not be qualified enough for the job. France is an interesting example where it is surprisingly discovered that people cannot get jobs not because they cannot do the job properly but because they cannot do the job interview properly (Centre Inffo, 2016). Helping these individuals acquire the soft skills they lack might encourage them to join labor force.

\subsection{Discussion, Suggestions and Conclusion for VET Workers}

We know that it is easier for enterprises to find VET workers in more developed and better educated regions. Although it is relatively easier for the more developed regions to find VET workers, 50 to $70 \%$ of enterprises in these regions express difficulties. In relatively less developed regions, more than $70 \%$ of enterprises struggle to find VET workers. This suggests a countrywide problem. In Turkey, individuals might get vocational education at a high school level (vocational high schools) and at a higher education level (vocational schools). In better educated regions, there are more high school and higher education graduates and therefore a larger labor force with vocational training.

Table 12: Relationship of Difficulty in Finding VET Worker and Unemployment of Higher Education Graduates by NUTS-2 Region

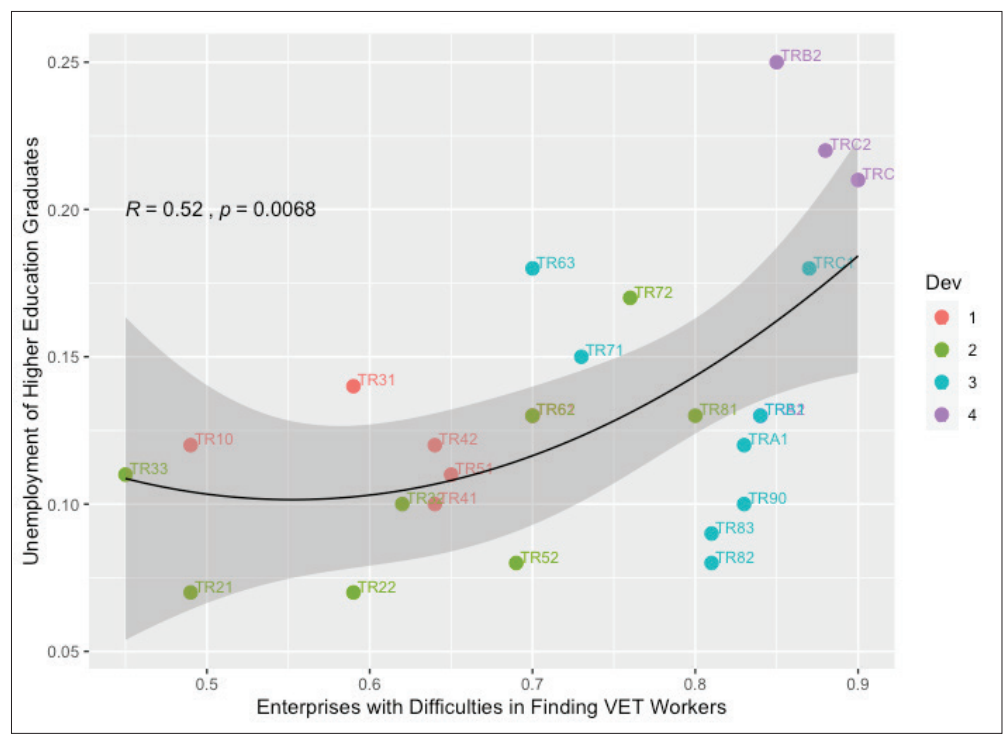

Source: VGM and TURKSTAT, Created by Author 
Table 12 below shows the percentage of enterprises which struggled to find VET workers on the $\mathrm{x}$-axis and the unemployment of higher education graduates on the y-axis. The table has a p-value of 0.0068 . Table 12 indicates that in regions where enterprises struggled more to find VET labor, the unemployment of higher education graduates was higher. Where enterprises could find VET labor easier, the unemployment of higher education graduates was lower.

A finding that supports earlier works in migration studies is that geographical location is a factor in helping enterprises to attract VET workers. In Turkey, the Eastern Anatolia Region and the Southern Anatolia Region lose their populations via migration to western provinces. Specifically, the Marmara Region attracts most of the migration as it is a big industrial hub (Anavatan, 2017). In short, the population migrates to western Turkey when there is migration. This is apparent in Table 12 above. Level 1 and 2 regions are separated at the $65 \%$ mark according to their geographical location. Level 1 and 2 regions, where less than $65 \%$ of enterprises stated difficulties in finding VET workers, are all located on the western coasts of Turkey. The only exception here is TR51 (Ankara), which scores $65 \%$ and is located in the center of Turkey, but it enjoys the advantage of being the capital city. Level 1 and 2 regions which are located in the east, on the other hand, have a range between 70 to $80 \%$. In this aspect, geographical location appears to be a huge decisive criterion in attracting VET workers.

Although this geographical phenomenon is apparent in level 1 and 2 regions, it has effects on level 3 and 4 regions, too. In level 3 and 4 regions, 80 to $90 \%$ of enterprises could not find the VET workers they needed. In these regions where almost none of the enterprises could find VET workers, the unemployment among higher education graduates was also the highest despite having a lower percentage of higher education graduates in their labor force. However, who are those higher education graduates in level 3 and 4 regions that do not satisfy the VET worker needs of enterprises at all?

Unfortunately, because TURKSTAT does not provide regional unemployment of vocational school graduates and other higher education graduates separately, we fall short in coming up with a plausible answer. However, when we review all the indicators, we come to the conclusion that the unemployed higher education graduates in level 3 and 4 regions are not vocational school graduates but rather other higher education graduates.

We already know that Turkish people choose to migrate westwards whenever they are in a position to choose. This is probably even more true for VET workers who are in demand across all of Turkey. Since the demand for VET workers is unsatisfied in every region, VET workers can migrate wherever they see fit. They are the choosers not the chasers here, and 
we can think of several factors that make level 3 and 4 regions less attractive for VET workers and make the situation harder for enterprises in level 3 and 4 regions.

The first factor is the geographical location. Geographical location is a decisive factor among level 1 and 2 regions already. Regions in the west attract more VET workers than regions in the east. However, there is more to it. Relative to level 1 and 2 regions, level 3 and 4 regions are mostly located in the east of the country. We believe level 1 and 2 regions which are in the west get a VET worker flow from level 3 and 4 regions in the east. This flow helps enterprises in level 1 and 2 regions find VET workers while making life harder for enterprises in level 3 and 4 regions. Geographical location is not the only advantage level 1 and 2 regions have. Being more developed, level 1 and 2 regions offer better education and a better environment to VET workers' children, better healthcare, and better living standards.

There are economic factors, too. In relatively less developed regions, the value added per worker is lower. This limits the wage that enterprises in level 3 and 4 regions can offer. Enterprises in level 1 and 2 regions, on the other hand, have a production with a higher value added per worker and can offer much more competitive wages to attract VET workers.

Although these factors might attract any higher education graduate, only the ones with a vocational background have a chance to choose. This is why we believe the unemployed higher education graduates in level 3 and 4 regions do not have a vocational education. They are unemployed despite the high demand for VET workers because they cannot satisfy the demand for VET workers. Since we do not have any concrete reason to believe that higher education institutions in level 3 and 4 regions are overwhelmingly non-vocational institutions, we believe the vocational school graduates migrate to other regions. They migrate because 1) they can do so due to high VET worker demand everywhere in Turkey, and 2) they want to do so as level 1 and 2 regions have more to offer.

This points to a big over-education problem in level 3 and 4 regions. Being a higher education graduate from a non-vocational institution in relatively less developed regions in Turkey is a free ticket to unemployment. There are not enough job opportunities for higher education graduates, and as a result, higher education graduates in these regions are either unemployed or underemployed.

However, the important finding here is that this over-education problem in level 1 and 2 regions is not as severe as it is in level 3 and 4 regions. TURKSTAT announced the unemployment rate at $11 \%$ for 2018 (TURKSTAT, 2020). Although there are some exceptions, most of the unemployment rates for higher education graduates in level 1 and 2 regions float around this level. In more developed regions, the mode of production requires higher education graduates more than that of level 3 and 4 regions. This finding is crucial. 
Over-education and over-qualification problems and their severity are not uniform across regions. Unlike level 3 and 4 regions, the problem is not over-education in level 1 and 2 regions. It is the lack of VET workers.

We will offer our solutions to help enterprises find VET workers later after a brief analysis of high school graduates. For now, we will briefly mention a solution to help higher education graduates that are unemployed in level 3 and 4 regions. This is a complicated problem, and there is no easy way out since even level 1 and 2 regions are saturated in nonvocational higher education graduates, if not are over-saturated. The only solution we can come up with is to increase the technology intensity of the production in these regions to create job opportunities for the highly-educated work force. This might be done via offering government funding to start-ups, incentives for other high-tech companies to move their operations, or by moving some governmental operations to these regions.

We will now focus on vocational education as high school education. Table 13 below shows the percentage of enterprises that struggled to find VET workers on the x-axis and the regional unemployment of high school graduates on the y-axis. The relation between these two variables has a p-value of 0.051 , so this relation is not significant at $95 \%$ level. Thus, we will not emphasize our inferences here, but there is one thing we believe is worth mentioning. Level 4 regions are in the top right again, just like in Table 12. In these regions, where enterprises struggled the most to find VET workers, unemployment among higher education graduates was the highest despite having the smallest percentage of high school graduates in their labor force composition. Just like the unemployed higher education graduates in level 3 and 4 regions, these high school graduates in the top right corner are of the kind which do not satisfy enterprises' needs for VET workers. Again, we believe vocational high school graduates of level 4 regions migrate to other, more developed regions.

Unlike higher education graduates, TURKSTAT provides the rate of unemployment of high school and vocational high school graduates separately. According to the TURKSTAT data from 2018, the unemployment among high school graduates with a non-vocational education is $14 \%$. It is $11.4 \%$ for ones with vocational training (TURKSTAT, 2018). Thus, we can say that the high school graduates with vocational training are in higher demand compared to the ones without. Unfortunately, TURKSTAT does not provide the rate of unemployment of vocational high school and other high school graduates separately by region to take this analysis any further. 
Table 13: Relationship of Difficulty in Finding VET Worker and Unemployment of High School Graduates by Region

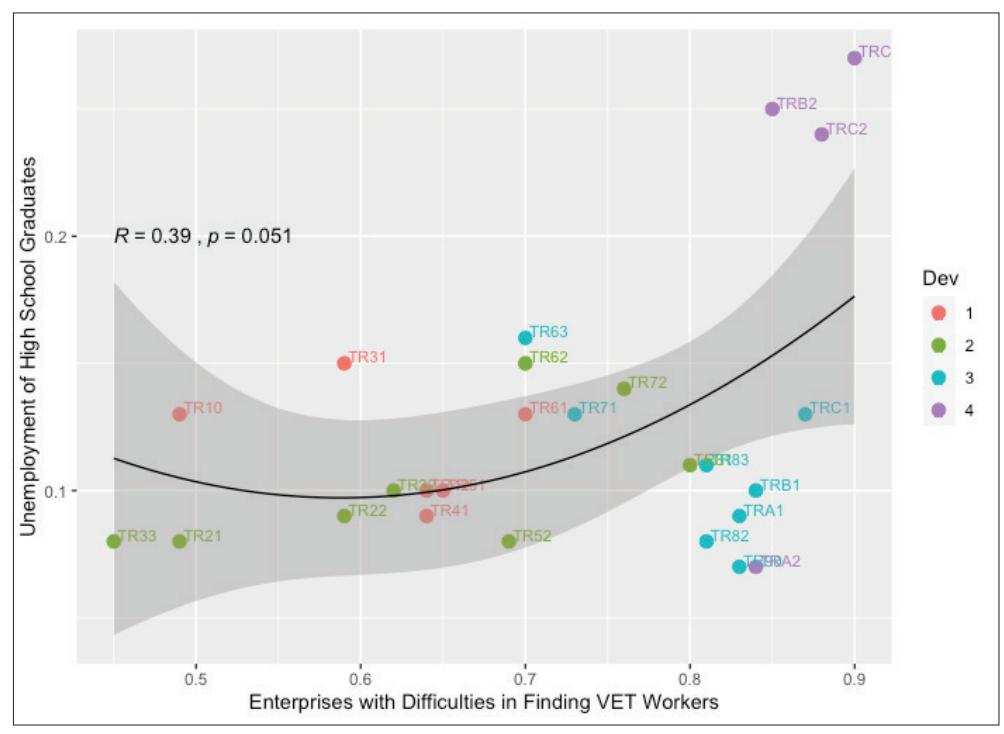

Source: VGM and TURKSTAT, Created by Author

What would be the solution for this problem of not being able to find VET workers? In normal conditions, we would expect more individuals to proceed to formal education with vocational training or to participate in extracurricular vocational courses as demand from enterprises increases. This does not appear to be the case in Turkey. Despite the dire need for VET workers, the portion of the labor force without a high school diploma is around $50 \%$ for level 1 regions, 55\% for level 2 and 3, and around 60\% for level 4 regions. For some reason, this portion of the labor force does not proceed to vocational high school as part of their formal education or participate in vocational training after their graduation to improve their employability, increase their wages, and satisfy the need of enterprises for VET workers. According to Eurostat numbers, lifelong learning participation among adults is recorded as $11.1 \%$ for European Union average and $6.2 \%$ for Turkey. For 2019, the EU average was $11.3 \%$ while it was half of that number, $5.7 \%$, for Turkey (Eurostat, 2020). Only a fraction of adults in Turkey participated in extracurricular training despite the huge need.

Our first suggestion to help enterprises find VET workers in the short-term is to upskill this portion of the labor force without high school education by encouraging individuals to participate in extracurricular vocational education and training. This solution would both lead to better wages and to higher employability for workers while increasing the chances of 
finding VET workers for enterprises. Organizations such as ISKUR and ISMEK already offer extracurricular training to individuals who volunteer. There might be several problems though. We already know that the curricula of life-long learning courses offered in Turkey are decided centrally instead of being designed according to the needs of sectors. These courses are not as beneficial as their potential due to this lack of communication (CEDEFOP, 2017). Improving the communication to accommodate the needs of enterprises could help designing better courses.

Another problem might be the lack of awareness of available courses or the potential benefits among individuals. If this is the case, organizations might look for ways to increase awareness for the earlier successes of the current courses available. The last problem might simply be the lack of area coverage and access to these courses. In such a case, shuttles to course centers or online training options could increase access and participation. There are many instances where successful VET programs struggle due to these basic problems and flourish only after small necessary adjustments (CEDEFOP,2015). Turkey has a huge untapped labor potential in its relatively less developed regions. By offering vocational training to individuals, the labor participation rate might increase to aid the needs of enterprises as well as increasing household incomes and increasing aggregate production in the economy.

These are the more specific solutions about high school and higher education graduates in Turkey that could be applied to the current situation of labor markets. There is one much more comprehensive solution we have to offer. We know that it has been getting harder and harder for higher education graduates to find a job in Turkey. Youth unemployment rose from $22 \%$ in 2018 to $27.6 \%$ in 2019 in Turkey (TURKSTAT, 2020). This means, the better educated younger generations of Turkey cannot compete against the more poorly educated but now-experienced older generations of Turkey. Since Turkey's youth cannot (or does not) acquire vocational skills, enterprises choose those of the older generations who have acquired these skills via experience. Especially in the less developed regions, the supply of workers with a vocational background does not meet the demand of enterprises. Enterprises have no reason to hire higher education graduates with non-vocational education, and they are in need of VET workers. The solutions we have offered so far were to give individuals who could not enter the labor force a second chance. Why should we not train them according to the needs of the sector in the first place? It is possible to revise the curricula of vocational high schools and vocational schools according to the needs of enterprises. Then, channeling the students into vocational education as part of their formal education would help them find jobs easier after their graduation and help them earn better wages while helping enterprises to find VET workers they are so in need of. Children or their parents (who often are the decision makers of the child at that age) might not be aware of the benefits of a vocational high school or the opportunities it offers in their high school decision process. An awareness 
campaign could help many children in their future. This solution would increase the aggregate efficiency and output of the whole economy as well.

We believe this imbalance in Turkish labor markets deserves attention. We hope this research will bring further light onto this problem and help policy makers come up with long awaited solutions.

\subsection{Limitations of the Study}

Throughout this research, we encountered several limitations that we believe we should carry over here. The first limitation we faced is the lack of extensive existing literature. Although there are couple of earlier works that we used throughout the paper and mentioned in the literature review section, we could not find any region-specific studies to base this study on. Skills-mismatch in Turkish labor markets remains pretty much untouched. Earlier studies examining regional labor markets and recent trends are another area we could not find any earlier works on.

The absence of detailed micro-level data is another limitation. First, we could not find any unemployment data that separated vocational school graduates and 4-year degree university graduates. TURKSTAT offers a single unemployment rate for higher education graduates as a whole. Other data we could not find were the unemployment of high school graduates and vocational high school graduates on regional basis. The sole existence of such a data would have helped some of the claims of this paper a lot and clear some of the points made here.

The last limitation we faced was the age of the data we had at hand. The data we used were from 2018 fiscal year. Although it is not very old, we still would have preferred a more recent data.

Peer-review: Externally peer-reviewed.

Conflict of Interest: The author has no conflict of interest to declare.

Grant Support: The author declared that this study has received no financial support.

\section{References}

Allen, J., \& Van der Velden, R. (2009). Competencies and Early Labour Transition of Higher Education Graduates. Anavatan, A. (2017). Türkiye'de iç göç ve belirleyicileri: mekansal veri analizi.

AŞIK, G. A. (2013). İşgücü Piyasalarının Göz Ardı Edilen Sorunları: Eksik İstihdam, Atıl İstihdam ve Beceri Uyuşmazlığı. Türkiye Ekonomi Politikaları Araştırma Vakfi Politika Notu, 1-11.

Berlingieri, F. (2019). Local labor market size and qualification mismatch. Journal of Economic Geography, 19(6), 1261-1286. 
CEDEFOP (2015). Tackling unemployment while addressing skill mismatch: lessons from policy and practice in European Union countries. Luxembourg: Publications Office. Cedefop research paper; No 46. http://dx.doi. org/10.2801/648140

CEDEFOP (2017). European inventory on validation of non-formal and informal learning - Turkey - 2016,

Centre Inffo (2016). Key competences in vocational education and training - France. Cedefop ReferNet thematic perspectives series. http://libserver.cedefop.europa.eu/vetelib/2016/ReferNet_FR_KC.pdf

Eurostat. (2020). Adult Participation in Learning by Sex (2.4.2-r2163-2018-08-17 (PROD)) [Dataset]. Retrieved from https://ec.europa.eu/eurostat/tgm/table.do?tab=table\&plugin=1\&language=en\&pcode=sdg_04_60

Galasi, P. (2008). The effect of educational mismatch on wages for 25 countries (No. BWP-2008/8). Budapest Working Papers on the Labour Market.

Kurnaz, I. (2014). "Bir kariyer stratejisi olarak "aşırı eğitimlilik": sıçrama tahtası mı? - tuzak mı?” İŞKUR; II. Uluslararası İş ve Meslek Danışmanlığı Kongresi Bildiri Kitabı, Antalya-Türkiye Kasım, 2014.

Manpower Group (Firm). (2018). 2019 Talent Shortage Survey.

Miner, R. (2014). The great Canadian skills mismatch: People without jobs, jobs without people and more. Miner Management Consultants.

Organisation for Economic Co-operation and Development, \& Organisation for Economic Co-operation and Development Staff. (2011). OECD employment outlook 2011. Paris: OECD Publishing.

SEGE (2017) İllerin ve Bölgelerin Sosyo-Ekonomik Gelişmişlik Sıralaması Araştırması Raporu, (Edited By: Salih ACAR, Dr. Leyla BİLEN KAZANCIK, Mustafa Caner MEYDAN, Mustafa IŞIK), Sanayi ve Teknoloji Bakanlığı Kalkınma Ajansları Genel Müdürlüğ̈̈, Report Number: 3, Ankara, 2017.

Siyaset, Ekonomi ve Toplum Araştırmaları Vakfı (SETA) (2012). Türkiye’nin İnsan Kaynağının Belirlenmesi. 73

Steiner, V., \& Mohr, R. (1998). Industrial change, stability of relative earnings, and substitution of unskilled labor in West-Germany (No. 98-22). ZEW Discussion Papers.

ŞAHIN, Ö. Analysis of Skills-Mismatch in Turkey-Suggestions for Vocational Education and Training Policies. Journal of Continuous Vocational Education and Training, 3(1), 33-46.

TÜİK (2020). Eğitim durumuna göre işgücü göstergeleri.

TÜİK (2020). İsgücü İstatistikleri

T.C. Bilim, Sanayi ve Teknoloji Bakanlığı, Verimlilik Genel Müdürlüğü Raporu, (2018). Türkiye Bölgesel Ve Sektörel Verimlilik Gelişim Haritalarinin Oluşturulmasi Projesi Saha Çalişmasi Analizi. https://docplayer.biz. tr/122551156-Turkiye-verimlilik-gelisim-haritasi.html

Zira, E. (2016). The impact of skill mismatch on aggregate productivity: Cross-country analysis in OECD economies. Unpublished master's thesis, KTH Industrial Engineering and Management, Stockholm, Sweden. 
